KOŚCIÓŁ I PRAWO 8(21) 2019, nr 1, s. 51-59

DOI: http://dx.doi.org/10.18290/kip.2019.8.1-4

\author{
Agnieszka Romanko
}

\title{
PODMIOTY ZOBOWIĄZANE DO WYCHOWANIA DZIECKA WEDŁUG STEFANA KARDYNAŁA WYSZYŃSKIEGO. WYBRANE ZAGADNIENIA
}

\section{POJECIE „WYCHOWANIE”}

Wskazywanie podmiotów zobowiązanych i odpowiedzialnych za wychowanie dziecka, było przedmiotem nie tylko licznych wypowiedzi Stefana Kardynała Wyszyńskiego, ale także badań naukowych - prowadzonych zanim jeszcze został kreowany kardynałem ${ }^{1}$. W duchu nauczania papieża

DR AgnieszKa RomanKo - adiunkt, Katedra Kościelnego Prawa Publicznego i Konstytucyjnego, Instytut Prawa Kanonicznego, Wydział Prawa, Prawa Kanonicznego i Administracji Katolickiego Uniwersytetu Lubelskiego Jana Pawła II; adres do korespondencji: Al. Racławickie 14, 20-950 Lublin, Polska; e-mail: agnieszka24@ku.pl; https://orcid.org/0000-0001-9206-747X

${ }^{1}$ Świadczy o tym przede wszystkim to, iż zagadnienia związane z wychowaniem oraz obowiązki konkretnych podmiotów względem młodego pokolenia w zakresie tego wychowania ks. Wyszyński zamierzał opisać w przygotowywanej pod kierunkiem ks. prof. Jana Wiślickiego - kierownika Katedry Publicznego Prawa Kościelnego - rozprawie doktorskiej wieńczącej studia na Katolickim Uniwersytecie Lubelskim (1925-1929). Przedmiotem obrony rozprawy doktorskiej nt. „Prawa Rodziny, Kościoła i Państwa do szkoły” uczynił jej rozdział II pt. „Prawa Kościoła do szkoły”, zob. Protokót z dnia 21 i 22 czerwca 1929 r. $w$ przedmiocie «obrony rozprawy $i$ tez dla otrzymania doktoratu $z$ prawa kanonicznego przez ks. Stefana Wyszyńskiego», w: Stefan Wyszyński Prymas Tysiqclecia absolwent KUL ... kandydat na ołtarze, red. M. Sitarz, A. Słowikowska, A. Romanko, Stowarzyszenie Absolwentów i Przyjaciół Wydziału Prawa Katolickiego Uniwersytetu Lubelskiego, Lublin 2017, s. 164, a także maszynopis rozprawy doktorskiej: Wyszyński 1929. Szerzej na temat przedmiotu pracy doktorskiej, jak i przebiegu obrony doktorskiej zob. Sitarz 2017a, 88-89; Tenże 2017c, 24-30. 
Piusa $\mathrm{XI}^{2}$ przypominał, że wychowanie jest dziełem społecznym, a nie jedynie poszczególnej jednostki. W związku z tym wyodrębniał trzy zasadnicze społeczności mające nie tylko prawa, ale przede wszystkim określone obowiązki w zakresie wychowania dziecka, tj. rodzinę i państwo - jako społeczności w porządku naturalnym oraz Kościół, czyli społeczność w porządku nadprzyrodzonym. Społeczności te nazywał „władzami wychowawczymi” [Wyszyński 1929, 20] i podkreślał konieczność ich wzajemnego współdziałania w służbie każdego człowieka, zwłaszcza tego najmniejszego i bezbronnego. „Współdziałanie władz wychowawczych: rodziny, szkoły, Kościoła, Państwa, narodu - jest zasadniczym warunkiem społecznego ładu. Warunkiem tego współdziałania jest, by w każdej uczelni, założonej bądź przez rodzinę, bądź przez Kościół, Państwo czy naród - wszystkie prawowite władze mogły spełniać swe obowiązki i wykonywać swe prawa” [tamże; Wyszyński 2016b, 303-14].

Poprzez wyszczególnienie społeczności w porządku naturalnym (doczesnym) i społeczności w porządku nadprzyrodzonym ukierunkowywał podmioty zobowiązane do wychowania na ukazanie podwójnego celu tego wychowania. Wychowanie bowiem - jak pisał J. Korzonkiewicz we wprowadzeniu do polskiego wydania encykliki Divini illius Magistri - to „zespół tych czynności, za pomocą których człowiek dojrzały człowieka niedojrzałego prowadzi do rozwoju sił fizycznych i umysłowych, a więc do samodzielności i pełności doskonałej tak, żeby ten człowiek mógł już własnemi siłami dążyć do podwójnego celu swego życia. O podwójnym celu mówi się dlatego, ponieważ zarówno czysto rozumowe rozważanie jakoteż objawienie dostarcza niezbitych dowodów, że człowiek nie zdoła osiągnąć prawdziwego udoskonalenia, jeżeliby się ograniczył do celów li tylko doczesnych: cała jego «konstytucja», wszystkie jego władze, skłonności i potrzeby żywiołowo i esencjonalnie zmierzają do celów, które leżą poza i ponad ograniczoną doczesnością" [Korzonkiewicz 1932, III-IV].

\footnotetext{
${ }^{2}$ Pius PP. XI, Litterae encyclicae de christiana iuventutis educatione Divini illius Magistri (31.12.1929), AAS 22 (1930), s. 49-86; tekst polski: Jego Świątobliwości Piusa PP. XI Encyklika o chrześcijańskiem wychowaniu młodzieży („Divini illius Magistri”) $z$ dnia 31 grudnia 1929 r. Na nowo z tacińskiego przełożył $i$ objaśnieniami opatrzyt X. Jan Korzonkiewicz, Nakładem Kancelarji Prymasa Polski, [b.m.w.] 1932.
} 
W dalszej części artykułu zostaną scharakteryzowane trzy podstawowe

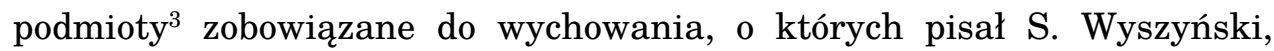
a także będą wskazane racje, dla których Prymas Tysiąclecia zwracał uwagę na ich współdziałanie.

\section{RODZINA}

Pierwszym posłannictwem i zadaniem rodziców jest dać życie, a następnie to życie wychowywać4. W 1966 r. podczas Uroczystości Świętej Rodziny S. Wyszyński mówił, że Kościół określa podwójne zadanie każdej rodziny, tj. zadanie własne - wzajemna pomoc i zadanie społeczne przekazanie życia następnym pokoleniom [Wyszyński 2016a, 79]. „Rodzice - mówił Stefan Kardynał Wyszyński - sprawują pierwsze posłannictwo Boże wobec swych dzieci. Z prawa Bożego i kanonicznego Rodzice czynią prawo i obowiązek zapewnienia dzieciom rodziny praktyk religijnych, którym przewodniczą (...) modlitwa, znak Krzyża Świętego, nauka wiary, miłość do Boga, ukazują dobro, kształtują myśl, zwracają uczucie dziecięce ku Bogu, rozwijają wyobrażenia religijne. Jako członkowie Kościoła, związani w sakramencie małżeństwa, rodzice sprawują te obowiązki religijne w rodzinie, poniekąd z upoważnienia Kościoła. Łaska sakramentalna działa tak potężnie w małżeństwie chrześcijańskim: wiernym tej łasce, że rodzice religijni zdolni są wszczepić w dusze swych dzieci ochrzczonych ducha Wiary" . Zagadnieniu rodziny - jako pierwszemu i podstawowemu podmiotowi zobowiązanemu do wychowania dzieci - ks. Wyszyński poświęcił założony w 1945 r. przez siebie tygodnik pt. „Ład Boży”, którego został pierwszym redaktorem naczelnym. Na łamach periodyku publikował

${ }^{3}$ Szerzej na temat rodziny, Kościoła i Państwa w kontekście ich „prawa do szkoły” w referacie A. Romanko pt. Prawa rodziny, Kościoła i Państwa do szkoły w interpretacji ks. Stefana Wyszyńskiego, wygłoszonym podczas Międzynarodowej Konferencji Naukowej „Stefan Kardynał Wyszyński - Nauczyciel praw Bożych” dnia 13 stycznia 2018 r. w Katolickim Uniwersytecie Lubelskim Jana Pawła II.

${ }^{4}$ „Małżeńskie przymierze, przez które mężczyzna i kobieta tworzą ze sobą wspólnotę całego życia, skierowaną ze swej natury do dobra małżonków oraz do zrodzenia i wychowania potomstwa (...)", zob. Codex Iuris Canonici auctoritate Ioannis Pauli PP. II promulgatus (25.01.1983), AAS 75 (1983), pars II, s. 1-317; tekst polski w: Kodeks Prawa Kanonicznego, przekład polski zatwierdzony przez Konferencję Episkopatu, Poznań 1984, kan. $1055 \S 1$.

${ }^{5}$ Cyt. za: Bartnik 1986, 227. 
artykuły [Wyszyński 1945a, 3; Tenże 1945b, 3; Tenże 1946a, 3; Tenże 1946b, 3; Tenże 1946c, 3; Tenże 1946d, 3; Tenże 1946e, 3; Tenże 1946f, 3; Tenże 1946g, 3; Tenże 1946h, 3; Tenże 1946i, 3], których treść miała docierać do każdej polskiej rodziny - rodziny doświadczonej skutkami II wojny światowej.

Rodzina jest podstawową komórką życia społecznego. Dlatego też państwo powinno tak wprowadzać ustawodawstwo życia rodzinnego, aby rodzice mieli możność poświęcić się w odpowiedniej mierze życiu rodzinnemu i wychowaniu swoich dzieci. Prymas Tysiąclecia podkreślał: „Rodzina musi wychowywać, a jeśli tego nie czyni «narusza prawa dziecka, prawa [tym A.R.] świętsze, że sam poszkodowany nie jest w stanie osobiście ich dochodzić»; prawo do wychowania rodzice mają z przyrodzenia i dlatego bez szkody dla społeczeństwa nie mogą zaniedbywać tego prawa, lub też całkowicie zeń zrezygnować” [Wyszyński 1929, 16-17]. Rodzice - jako pierwsi nauczyciele - mają nie tylko prawo, ale przede wszystkim obowiązek wychowywania dzieci zgodnie z własnymi przekonaniami ${ }^{6}$. Obowiązek do wychowania przysługuje rodzicom z samego faktu bycia rodzicami, z faktu, że przekazali dziecku życie. Dlatego też nie mogą oni zaniedbywać tego obowiązku lub z niego całkowicie zrezygnować [Sitarz 2005, 87-98; Tenże 2017b, 63-86]. Uzupełnieniem procesu wychowawczego zapoczątkowanego $\mathrm{w}$ rodzinie, niejako mandatariuszem rodziny jest szkoła, jednak nie może ona całkowicie zastąpić wychowania w rodzinie [Wyszyński 1929, 16-17].

Zdaniem Prymasa obowiązek wychowania dziecka przez rodziców obejmuje wychowanie zarówno zdrowego ciała, jak i zdrowej duszy. Zwracał się do rodziców: „Unikajcie przesądu, że wasze osobiste życie duchowe i moralne nie wpływa na wasze maleństwo. Od początku twojego, Matko, związku z twoim dziecięciem wpływasz na nie i to nie tylko przez krew twoją, ale i przez twoją duszę. Jaką Ty masz duszę, Matko, taką w dużej mierze wartość duchową przedstawiać będzie twoje dziecię. Zwłaszcza, gdy urodziwszy je w duchowej łączności z Bogiem, będziesz je wychowywać w łączności z Bogiem. To wielkie wasze zadanie, Rodzice katoliccy: wychować duszę! A dalej - kontynuował kard. Wyszyński - trzeba nauczyć dziecię szlachetnego sposobu życia, przygotować je do życia. Nie wystarczy rzucić je w świat i powiedzieć: radź sobie! Nie, Rodzice, wasz obowiązek i odpowiedzialność za dzieci trwa długie lata. Do Was należy tak uformować

\footnotetext{
${ }^{6}$ Szerzej zob. Maziarczuk 2017.
} 
i ukształtować dziecię, tak je przyzwyczaić do praktycznego życia, by już łatwo umiało sobie poradzić ze sobą, gdy będzie samodzielne" [Wyszyński 1986b, 134]. Zapoczątkowane wychowanie dzieci przez rodziców w domu rodzinnym, powinno być następnie prowadzone w instytucjach wychowawczych i w życiu społecznym. Rodzice mają obowiązek nad tym czuwać. Prymas Tysiąclecia traktował rodzinę jako jeden z podstawowych czynników odrodzenia Kościoła i narodu, mówił: „Naród zabezpiecza się bardziej w rodzinie niż w granicach Państwa. Granice Narodu i Państwa płyną poprzez kołyski”7.

\section{PAŃSTWO}

Państwo - według Stefana Kardynała Wyszyńskiego - nie może być bierne na właściwe wychowanie i wykształcenie członków społeczności doczesnej. Ma ono w tym zakresie zobowiązania opieki i nadzoru. Jako społeczność suwerenna, mająca własne cele - zabezpieczenie dobrobytu społecznego swym członkom, może je realizować wtedy, gdy wdroży ludzi do szanowania praw ułatwiających współżycie. Stąd musi wglądać w prace wychowawcze, określać bliżej warunki wychowania. Władzy państwowej powinno zależeć na dobrym wychowaniu w rodzinie, w szkole, także na wychowaniu religijnym [Wyszyński 1929, 19]. Celem państwa jest zapewnienia dobrobytu społecznego swoim obywatelom. Dlatego też społeczność państwowa nie może być obojętna na pełne wychowanie człowieka. Zadaniem państwa jest zatem gwarantować i chronić przysługujące innym podmiotom prawa w zakresie wychowania.

Uzasadniając zobowiązanie państwa do wychowania dziecka, Prymas podkreślał, że wychowanie dokonuje się w sferze nadprzyrodzonej i przyrodzonej. Młodego człowieka należy wychowywać w świadomości, że każda osoba ludzka jest najwyższą wartością zarówno w porządku przyrodzonym (świeckim), jak i w porządku nadprzyrodzonym (Bożym). Człowiek bowiem jest nie tylko elementem konstytutywnym Narodu wraz z określonymi prawami i obowiązkami, ale także członkiem Kościoła [Bartnik 1986, 231]. Społeczność państwowa - obok rodziny i Kościoła - powinny współpracować w wychowaniu. S. Wyszyński mówił, że „w wychowaniu młodzieży, jeśli ono

\footnotetext{
${ }^{7}$ Cyt. za: Bartnik 1986, 230.
} 
ma odpowiadać potrzebom współczesnym, musi brać udział nie tylko szkoła, ale wszystkie czynniki: rodzinne, religijne, moralne, państwowe, kulturalnospołeczne, zawodowe" [Wyszyński 1933, 176]. W porządku przyrodzonym podkreślał prymat rodziny i prymat życia, a w konsekwencji znaczenie wychowania: „Z prymatem rodziny, z prymatem życia i ładu ekonomicznego wiąże się inne doniosłe zadanie rodzinne - wychowania w Narodzie, wychowania osobistego i społecznego, czyli takiego ukierunkowania młodego Polaka, aby wchodził on w życie publiczne, społeczne i zawodowe w poczuciu przede wszystkim swoich obowiązków, które ma do wykonania, oraz w poczuciu praw, które posiada w Ojczyźnie” [Wyszyński 1986a, 464].

\section{KOŚCIÓE}

Kard. Wyszyński wywodził prawo i obowiązek Kościoła do wychowania z perspektywy porządku nadprzyrodzonego: „Nadprzyrodzona interwencja Boża w świecie, powołała człowieka do wyższych celów, dając mu za podstawę życia objawione prawdy wiary i wynikające $\mathrm{z}$ nich zasady moralne. Założony przez Chrystusa Pana Kościół otrzymał obowiązek czuwania nad zachowaniem $\mathrm{w}$ nieskażoności prawd wiary i moralności, a przez odpowiednie wychowanie ludzi - pomagania im w dążeniu do celu ostatecznego. Tak więc Kościół stanął w rzędzie instytucji wychowawczych, obok rodziny i państwa, mając właściwą sobie dziedzinę - wychowanie religijne i zależne od niego wychowanie moralne" [Wyszyński 1929, 21].

Prawo Kościoła do formowania dzieci i młodzieży wynika z zasadniczej misji Kościoła jako suwerennej społeczności. Urząd nauczycielski został ustanowiony przez Chrystusa, który nakazał swoim uczniom: „Idźcie i nauczajcie wszystkie narody (...)" (Mt 28,19) ${ }^{8}$. Jest to prawo powszechne i absolutne. „Stąd też prawo to nie może podlegać żadnej dyskusji, musi być uznawane jeśli się nie chce zaprzeczyć najistotniejszej roli Kościoła” [Wyszyński 1929, 25]. Ponadto podkreślał, że obowiązek ten ma również swoje uzasadnienie historyczne. W kontekście polskiej kultury i historii wskazywał na znaczenie religii w szkole ${ }^{9}$. Kościól ma prawo własne

${ }^{8}$ Pismo Święte Starego i Nowego Testamentu w przekładzie z języków oryginalnych. Opracował Zespół Biblistów Polskich z inicjatywy Benedyktynów Tynieckich, Pallottinum, Poznań $2008^{5}$.

9 „Jak bardzo życie Kościoła zrosło się z samą funkcją wychowawczą, nauczycielską, świadczy o tem historja; to też trudno jest mówić o historji szkolnictwa, wychowania wogóle, bez uwzględnienia roli Kościoła" [Wyszyński 1929, 40]. Zob. także Sitarz 2017c, 28. 
i obowiązek nauczania zasad wiary i moralności zgodnie z wymaganiami Chrystusa. Kościół występuje jako współpracownik rodziców, m.in. ponieważ uzupełnia ich wychowanie, poprzez zakładanie szkół katolickich i kierowanie nimi. Zawsze jednak - w odniesieniu do nauczania religii - ma prawo i obowiązek domagać się, aby wszyscy mandatariusze Kościoła współpracowali pod kierunkiem i nadzorem Kościoła, aby w ten sposób mieć pewność, że młodzieży jest podawana nauka zdrowa, wolna od błędów [Wyszyński 1929, 25].

\section{WNIOSKI}

Z przeprowadzonej analizy podmiotów zobowiązanych do wychowania dziecka według Stefana Kardynała Wyszyńskiego, należy wyprowadzić następujące wnioski.

1) Nauczanie Prymasa Tysiąclecia, chociaż odczytywane w innych okolicznościach miejsca i czasu, jawi się jako aktualne i niezmienne.

2) Kardynał Wyszyński wskazywał 3 główne podmioty zobowiązane do wychowania dziecka: rodzinę, państwo i Kościół.

3) Rodzice, ponieważ dali dziecku życie, zobowiązani są to życie wychować zarówno w płaszczyźnie fizycznej, jak i duchowej. Rodzice są pierwszymi wychowawcami, zaś instytucje państwowe i kościelne powinny wspierać ich $\mathrm{w}$ procesie nauczania $\mathrm{i}$ wychowania swoich dzieci zgodnie $\mathrm{z}$ własnymi przekonaniami.

4) Kościół Katolicki jest społecznością nauczającą i ma prawo absolutne i wyłączne nauczania zasad wiary. Do Kościoła należy kierownictwo moralne w nauczaniu i wychowaniu młodzieży chrześcijańskiej. Z kolei podstawowym zadaniem państwa jest zabezpieczenie dobrobytu społecznego obywatelom, dlatego nie powinno pozostawać bierne wobec właściwego wychowywania młodego pokolenia. 


\section{PIŚMIENNICTWO}

Bartnik, Czesław, red. 1986. Polska teologia Narodu. Lublin: Towarzystwo Naukowe KUL.

Korzonkiewicz, Jan. 1932. „Słowo wstępne.” W Jego Świqtobliwości Piusa PP. XI Encyklika o chrześcijańskiem wychowaniu młodzieży (,Divini illius Magistri”) z dnia 31 grudnia 1929 r. Na nowo z tacińskiego przetożyt i objaśnieniami opatrzył X. Jan Korzonkiewicz, I-XI. [b.m.w.]: Nakładem Kancelarji Prymasa Polski.

Maziarczuk, Sylwia. 2017. „Obowiązek i uprawnienie rodziców do wychowania dzieci według prawa kanonicznego.” Rozprawa doktorska, Katolicki Uniwersytet Lubelski Jana Pawła II.

Sitarz, Mirosław. 2005. „Funkcja wychowawcza rodziny w prawie publicznym.” Zeszyty Prawnicze Wyższej Szkoły Zarzqdzania i Prawa w Warszawie 17, z. 1:87-98.

Sitarz, Mirosław. 2017a. „Lata studenckie Księdza Stefana Wyszyńskiego w Lublinie.” Biuletyn Stowarzyszenia Absolwentów i Przyjaciót Wydziatu Prawa Katolickiego Uniwersytetu Lubelskiego XII, $\mathrm{nr} 14$ (1): 81-101.

Sitarz, Mirosław. 2017b. „Ochrona funkcji wychowawczej rodziny w prawie kanonicznym.” W Matżeństwo i rodzina w prawie kanonicznym $i$ w prawie polskim, red. Józef Krukowski, Mirosław Sitarz, i Janusz Gręźlikowski, 63-86. Lublin: Towarzystwo Naukowe KUL.

Sitarz, Mirosław. 2017c. „Stefan Wyszyński - od dzieciństwa do absolwenta KUL.” W Stefan Wyszyński Prymas Tysiaclecia - absolwent KUL ... kandydat na ottarze, red. Mirosław Sitarz, Anna Słowikowska, i Agnieszka Romanko, 9-34. Lublin: Stowarzyszenie Absolwentów i Przyjaciół Wydziału Prawa Katolickiego Uniwersytetu Lubelskiego.

Sitarz, Mirosław, Anna Słowikowska, i Agnieszka Romanko, red. 2017. Stefan Wyszyński Prymas Tysiaclecia - absolwent KUL ... kandydat na oltarze. Lublin: Stowarzyszenie Absolwentów i Przyjaciół Wydziału Prawa Katolickiego Uniwersytetu Lubelskiego.

Wyszyński, Stefan. 1929. „Prawa rodziny, Kościoła i państwa do szkoły.” Rozprawa doktorska, Katolicki Uniwersytet Lubelski.

Wyszyński, Stefan. 1933. „Społeczeństwo i prasa a wychowanie młodzieży.” Ateneum Kaplańskie 32, z. 2:175-88.

Wyszyński, Stefan. 1945a. „Kościół a wychowanie nowego człowieka.” Ład Boży 1, nr 10:3.

Wyszyński, Stefan. 1945b. „Wychowanie nowego człowieka.” Ład Boży 1, nr 9:3.

Wyszyński, Stefan. 1946a. „Co daje rodzina państwu?.” Ład Boży 2, nr 1:3.

Wyszyński, Stefan. 1946b. „Co należy się rodzinie od państwa?.” Ład Boży 2, nr 4:3.

Wyszyński, Stefan. 1946c. „Ochrona rodziny przez prawo państwa.” Ład Boży 2, nr 5:3.

Wyszyński, Stefan. 1946d. „Rodzina a Kościół i Państwo w wychowaniu.” Lad Boży 2, nr 33:3.

Wyszyński, Stefan. 1946e. „Rodzina i wychowanie.” Ład Boży 2, nr 25:3.

Wyszyński, Stefan. 1946f. „Trudności współpracy w wychowaniu.” Ład Boży 2, nr 30:3.

Wyszyński, Stefan. 1946g. „Współpraca w wychowaniu dzieci.” Ład Boży 2, nr 28:3.

Wyszyński, Stefan. 1946h. ,Wychowawcze prawa rodziców.” Ład Boży 2, nr 26:3.

Wyszyński, Stefan. 1946i. „Zasady współpracy w wychowaniu.” Ład Boży 2, nr 31:3.

Wyszyński, Stefan. 1986a. „Odpowiedzialność - obowiązki - prawa w życiu narodu.” W Stefan kardynat Wyszyński. Glos z Jasnej Góry, 461-68. Warszawa: Akademia Teologii Katolickiej.

Wyszyński, Stefan. 1986b. „Rodzice, nadeszła wasza godzina. Do Małżonków katolickich. 15 sierpnia 1961 r.” W Stefan kardynat Wyszyński. Głos z Jasnej Góry, 131-37. Warszawa: Akademia Teologii Katolickiej. 
Wyszyński, Stefan. 2016a. „Dążenie do rodziny, rodzinności, wspólnoty - właściwością natury ludzkiej." W Stefan Kardynat Wyszyński. Prymas Polski. Dzieła zebrane. Tom XVI styczeńkwiecień 1966, red. Iwona Czarcińska, Beata Mackiewicz, i Anna Rastawicka, 75-80. Warszawa: Wydawnictwo im. Stefana Kardynała Wyszyńskiego Soli Deo.

Wyszyński, Stefan. 2016b. „Wychowanie w szkole w wolności i miłości.” W Stefan Kardynat Wyszyński. Prymas Polski. Dzieła zebrane. Tom XIV styczeń-maj 1965, red. Maria Bujnowska, Iwona Czarcińska, Beata Mackiewicz, i Anna Rastawicka, 303-14. Warszawa: Wydawnictwo im. Stefana Kardynała Wyszyńskiego Soli Deo.

Podmioty zobowiązane do wychowania dziecka według Stefana Kardynała Wyszyńskiego. Wybrane zagadnienia

$$
\text { Streszczenie }
$$

Wychowanie dziecka stanowiło przedmiot licznych wypowiedzi Stefana Kardynała Wyszyńskiego. W związku z tym wyodrębniał trzy zasadnicze społeczności mające nie tylko prawa, ale przede wszystkim określone obowiązki w zakresie wychowania dziecka, tj. rodzinę i państwo - jako społeczności w porządku naturalnym oraz Kościół, czyli społeczność w porządku nadprzyrodzonym. Społeczności te nazywał ,władzami wychowawczymi” i podkreślał konieczność ich wzajemnego współdziałania w służbie każdego człowieka.

Słowa kluczowe: rodzina; dziecko; Państwo; Kościół

\section{Entities Obliged to Raise a Child According to Stefan Cardinal Wyszynski. Selected Issues}

\section{Su m m a r y}

The upbringing of the child was the subject of numerous statements by Stefan Cardinal Wyszynski. In this regard, he distinguished three basic communities which had not only rights but above all specific duties in the area of child-raising, namely the family and the State - as communities in the natural order, and the Church, that is, a community in the supernatural order. He called these societies "educational authorities" and emphasized the necessity of their mutual cooperation in the service of every human being.

Key words: family; child; State; Church

Information about Author: Agnieszka Romanko, Ph.D. - assistant professor, Department of Public and Constitutional Church Law, Institute of Canon Law, Faculty of Law, Canon Law and Administration at the John Paul II Catholic University of Lublin; Al. Racławickie 14, 20-950 Lublin, Poland; e-mail: agnieszka24@ku.pl; https://orcid.org/0000-0001-9206-747X 